NBER WORKING PAPER SERIES

\title{
IMPACTS OF ELIGIBILITY EXPANSIONS \\ AND PROVIDER REIMBURSEMENT RATE INCREASES ON CHILD CARE SUBSIDY TAKE-UP RATES, WELFARE USE AND WORK
}

\author{
Ann Dryden Witte \\ Magaly Queralt \\ Working Paper 9693 \\ http://www.nber.org/papers/w9693
NATIONAL BUREAU OF ECONOMIC RESEARCH
1050 Massachusetts Avenue
Cambridge, MA 02138
May 2003

The work reported in this paper was supported by grant \#90YE0032 from the Child Care Bureau, Administration for Children and Families (ACF), U.S. Department of Health and Human Services (DHHS). The grant was awarded to the Wellesley Child Care Research Partnership through the National Bureau of Economic Research. Earlier work on this project and data collection were supported by a grant from the Rhode Island Department of Human Services (DHS) to the Wellesley Child Care Research Partnership. The support of DHS and DHHS for this work does not indicate their concurrence with our results, nor are DHS or DHHS in any way responsible for errors that we may have made. This project would not have been possible without the support of many people in Rhode Island. Sherry Campanelli, Reeva Murphy, Randy Rosati, Donalda Carlson, and Catherine Walsh provided invaluable guidance. They helped us to document and understand Rhode Island's child care policy changes associated with Starting RIght. Sherry Campanelli also provided us with contacts in various Rhode Island agencies in addition to DHS, such as the Department of Transportation, the Department of Education and the Department of Labor and Training (DLT), and with valuable comments and suggestions on earlier drafts of this report. She worked with us to develop a time line of changes taking place during the study period. Randy Rosati worked with us to develop data requests, and he worked with us and with employees of Network Six to extract data from DHS's administrative databases. He provided numerous interpretations and guides as our work progressed. He also worked with us and with personnel at DLT to obtain quarterly earnings reports from the Unemployment Insurance database. On the policy front, we would like to thank Nancy Tikkanen for helping us to understand the Family Independence Program (FIP) and Dorothy Karolyshyn for helping us understand the nuances of child care policies and other social welfare regulations in Rhode Island. Kim Keating and Louisa Tarullo helped us to obtain Head Start data and to understand the changes in Head Start that have occurred during welfare reform. Laura Beavers provided us with valuable data from Rhode Island's Kids Count historical databases. Marie Gariepy provided us with data on public school kindergarten programs. We also wish to express our appreciation to Dr. Pia Divine from the Child Care Bureau. Finally, Sherry Campanelli, Karen Tvedt (Child Care Bureau) and Helen Tauchen (UNC Chapel Hill) provided valuable comments and suggestions. The views expressed herein are those of the authors and not necessarily those of the National Bureau of Economic Research.

(C)2003 by Ann Dryden Witte and Magaly Queralt. All rights reserved. Short sections of text not to exceed two paragraphs, may be quoted without explicit permission provided that full credit including $O$ notice, is given to the source. 
Impacts of Eligibility Expansions and Provider Reimbursement Rate Increases on Child Care Subsidy Take-Up Rates, Welfare Use and Work

Ann Dryden Witte and Magaly Queralt

NBER Working Paper No. 9693

May 2003

JEL No. I38, H40, J22, I20

\begin{abstract}
We find that reforms in the Rhode Island subsidized child care program, including income and age eligibility expansions and increases in the reimbursement rates paid to formal providers, significantly increased the likelihood that current and former welfare families: a) would use child care subsidies and b) would work 20 or more hours per week. In addition, these policy changes significantly increased the probability that family heads of household would leave welfare for work.

The most powerful impact of the Rhode Island changes in child care policies was on families that had left welfare (i.e., former cash recipients) and that worked at least 20 hours per week. These policy changes had less effect on families receiving cash assistance and enrolled in some approved activity (e.g., education or training) other than work. We were not able to assess the impact of the Rhode Island policy changes on families who were never on cash assistance. However, the large increase in the number of such families receiving child care subsidies after the reforms were instituted suggests that the impact may have been substantial.
\end{abstract}

We also estimate that Rhode Island's reform of its cash assistance program and of its child care subsidy program, in combination, almost tripled the probability that a typical head of household currently or formerly receiving welfare would work 20 or more hours per week (i.e., the probability increased from $7 \%$ in the second quarter of 1996 to $22 \%$ in the second quarter of 2000) and almost halved the probability that a single mother in the sample would be on cash assistance and neither working nor in some other approved activity (i.e., such probability decreased from $47 \%$ in the second quarter of 1996 to $25 \%$ in the second quarter of 2000).

Ann Dryden Witte

Department of Economics

Wellesley College

Wellesley, MA 02481

and NBER

AWitte@Wellesley.edu
Magaly Queralt

Wellesley College Child Care Research Partnership Wellesley College

Wellesley, MA 02481

MQueralt@Wellesley.edu 


\section{Impacts of Eligibility Expansions and Provider Reimbursement Rate Increases on Child Care Subsidy Take-Up Rates, Welfare Use and Work}

Many important policy changes took place in Rhode Island as a result of the State's 1999 reform of its child care subsidy program. In this paper, we assess the impacts of income and age eligibility expansions and of provider reimbursement rate increases on the take-up rate for child care subsidies and on the likelihood that a family would leave welfare and work 20 or more hours per week.

Rhode Island's reform of its child care subsidy program during the 1990s is considered to be among the most comprehensive and innovative in the U.S. The policy changes were undertaken to provide additional supports to low-income families and to ensure that all children were given an opportunity to benefit from quality early care and education and before-school and after-school services. The changes created a child care subsidy system that better assists those receiving cash assistance in their journey from welfare to work and that better supports working families. For cash assistance recipients in Rhode Island, eligibility for a child care subsidy is based solely on employment or enrollment in some other approved activities (e.g., education or training) and on having an age-eligible child in the family. ${ }^{1}$ For former cash assistance recipients and other low-income families, eligibility is based on being employed, having income below the income-eligibility cut off and having an age-eligible child. As part of the reform of its child care subsidy program, Rhode Island substantially increased the maximum income allowed and the maximum child age eligible to receive subsidized child care. The State also increased dramatically the reimbursement rates paid to formal providers caring for subsidized children. 
In this paper, we estimate the direct impacts of eligibility expansions and the indirect effects of increased provider reimbursement rates on family demand for subsidized child care (i.e., take-up rates), cash assistance receipt and employment. We are unable to estimate direct effects of provider reimbursement rate increases because these increases directly affect child care providers and only indirectly affect eligible families. Therefore, we estimate their indirect impacts on families due, for example, to increased recruitment efforts by providers.

Evaluating the impact of child care policy changes requires considerable care because of the multiplicity of other changes that occurred during the period over which the child care policy changes were implemented. For example, during the implementation period, Rhode Island, like many other parts of the country, experienced rapid growth in overall employment. Beginning in May 1997, the State reformed its cash assistance program. In order to estimate the effects of the child care policy changes on cash assistance receipt, on employment, and on the use of child care subsidies, it is necessary to separate the impacts of employment growth and of the reform of the cash assistance program from the effects of the child care policy changes.

Building upon ongoing work in Rhode Island, Massachusetts and Florida (Witte \& Queralt, 2002; Witte, Queralt \& Tauchen, 2001; Lemke, Witt \& Witte, 2001; Queralt, Witte, and Griesinger, 2000; Witte, Queralt, Chipty \& Grisinger, 1998), we begin by developing a model for the probability that low-income single mothers who are current or former cash assistance recipients will be in one of various statuses, depending on whether or not they are: a) working 20 or more hours per week, b) receiving cash assistance, and c) receiving a child care subsidy. (These statuses are depicted in Figure 1 following the paper). The probability that such single mothers will be in one of the eight statuses in Figure 1 is dependent upon several factors. These include the family's relative well being in a particular status, the rules and requirements

\footnotetext{
${ }^{1}$ All families receiving cash assistance in Rhode Island have income levels that make them "income-eligible" for child care subsidies.
} 
of the cash assistance and of the child care subsidy program, the local labor and child care market conditions, and the characteristics of the residential neighborhood and the family (e.g., health status and age and number of children). We estimate the model using a multinomial logit procedure and quarterly longitudinal data that contains information on all working-age, female-headed, current or former welfare families in Rhode Island from May 1996 through April 2000.

We use the results of the model to predict the likelihood that an eligible family will use child care subsidies in each quarter of our study and the probability that a typical member of the sample will be in each of the eight statuses depicted in Figure 1 during each quarter. Finally, using these predictions, analysis of variance, and difference in differences, we estimate the impact of the eligibility expansions and of the increased recruitment efforts of formal providers as a result of the reimbursement rate increases.

We estimate that the child care policy reforms in Rhode Island led to large and significant increases in the likelihood that current and former welfare recipients working 20 or more hours per week would use child care subsidies. We find no significant impact of the child care policy changes on the likelihood of child care subsidy use among welfare recipients who are not working or who are working fewer than 20 hours per week and who are eligible to receive child care subsidies due to their participation in approved activities, such as education or training.

Using a difference in differences approach that controls for unobservable cross sectional and time varying effects, we estimate that, on average, the probability of being in Status 5 (i.e., not receiving cash assistance, working 20 or more hours per week and receiving child care subsidies) increased by slightly more than 3 percentage points (i.e., $3 \%$ ) as a result of the child care policy reforms in Rhode Island, and the likelihood of being in Status 3 (i.e., receiving cash 
assistance, working 20 or more hours per week, and receiving a child care subsidy) increased, on average, by a little over $1 \%$. Both of these results are significant at any normal level of statistical significance (e.g., .01, .001).

To state the results described above somewhat differently, between the first quarter of 1999 (Q1 of 1999) and the second quarter of 2000 (Q2 of 2000), we estimate that, as a result of the child care policy reforms that took place, on average, almost 1000 additional Rhode Island families per quarter were in Status 5 (i.e., not receiving cash assistance, working 20 or more hours per week and receiving child care subsidies), and approximately 350 additional Rhode Island welfare families per quarter were in Status 3 (i.e., receiving cash assistance, working 20 or more hours per week, and receiving a child care subsidy). ${ }^{2}$

As might be expected, the effects of the reform of the child care subsidy program were larger in later periods than immediately after the reforms. In the final quarter of our study, the second quarter of 2000 (Q2 of 2000), we estimate that, as a result of the child care policy reforms the typical family head in our sample was $5.7 \%$ more likely to be in Status 5 (i.e., not on cash assistance, working 20 or more hours per week and receiving child care subsidies) and current recipients were $1.75 \%$ more likely to be in Status 3 (i.e., on cash assistance, working 20 or more hours per week, and receiving a child care subsidy). This implies that, during Q2 of 2000, approximately 1680 additional RI families were in Status 5 (i.e., not on cash assistance, working 20 or more hours per week and receiving child care subsidies) and 516 additional cash

\footnotetext{
${ }^{2}$ Our numbers are derived from the probabilities reported in Table 4 at the end of the paper (for Status 5 a diff in diff p. of 0.031 and for Status 3 a diff in diff p. of 0.012), applied to our sample of 29,468 single-parent lowincome current and former welfare recipient families. Specifically, without child care reform (and controlling for all the factors in our model), between Q1 of 1999 and Q2 of 2000, we would have expected approximately 354 additional families per quarter to be in Status 5. After child care reform, we estimate 1267 additional families per quarter to be in Status 5 . This is a gain of approximately 914 families per quarter. Similarly, without child care reform, between Q1 of 1999 and Q2 of 2000, we would have expected approximately 766 additional families per quarter to be in Status 3. After child care reform, we estimate 1120 additional families per quarter to be in Status 3 . This is a gain of approximately 354 families per quarter.
} 
assistance recipients were in Status 3 (i.e., on cash assistance, working 20 or more hours per week, and receiving a child care subsidy) as a result of the child care policy reforms.

This paper is structured as follows. In section 1, we describe the setting for the study. Section 2 contains a description of the Rhode Island child care subsidy program during the period of our study, May 1996 to April 2000, and the major policy changes associated with Rhode Island's reform of its child care subsidy program. In Section 3, we develop the model that we use to structure our multivariate work and in section 4 we describe the data. Section 5 contains a description of the empirical specification for the multivariate work, and section 6 briefly describes some implications of the multivariate results. In Section 7, we describe how we estimate the impacts of the child care policy reforms and we present our results. Section 8 contains our conclusions. The paper is followed by Appendix A, which describes the Family Independence Program (Rhode Island's Welfare Reform program). This appendix is followed by the References and the Figures and Tables.

\section{The Setting - State Of Rhode Island}

Rhode Island (RI) is the smallest of the New England states and has a population of $1,048,319$, according to the year 2000 Census (U.S. Bureau of the Census, 2002). The State occupies a small land area--1,045 square miles--and has a density of 1,003 persons per square mile. Compared to the U.S. as a whole, which has a population density of 80 persons per square mile, RI is very densely populated.

According to the 2000 Census, the RI population is $82 \%$ non-Hispanic/non-Latino white, 8.7\% of Hispanic/Latino origin (of any race), $4.5 \%$ black or African American, and 2.3\% Asian. American Indians, Alaska natives, native Hawaiians, and Pacific Islanders comprise less than $1 \%$ of the population (U.S. Bureau of the Census, 2002). Compared to the State population, there are disproportionate numbers of Hispanics and blacks receiving child care subsidies in RI. 
In April 2001, among those receiving child care subsidies for whom there is racial or ethnic background information in the Department of Human Services (DHS) administrative files (i.e., $84 \%$ of child care subsidy recipients), $52 \%$ were white, $32 \%$ were Hispanic, $17 \%$ were black, and $1 \%$ were Asian or Pacific Islanders.

According to the 2000 Census, the 1999 poverty rate in RI for individuals of all ages was $11.9 \%$, somewhat under the $12.7 \%$ poverty rate for the U.S. population. For children, the poverty rate in RI in 1999 was $16.5 \%$, compared to $20.5 \%$ poverty rate for children in the U.S. population. However, poverty is highly concentrated in the core cities in RI, particularly in Providence, Central Falls, Woonsocket, and Newport. Census 2000 data revealed a poverty rate (among children under age 18 ) of $40.1 \%$ in Providence, $40.8 \%$ in Central Falls, $31.3 \% \%$ in Woonsocket, $23.8 \%$ in Newport, and 24.5\% in Pawtucket (U.S. Bureau of the Census, 2002).

According to the 2000 census, median household income in 1999 in RI was $\$ 42,090$, compared to $\$ 40,816$ for the U.S. as a whole. In $2000,78 \%$ of the population 25 years of age and over in RI were high school graduates and $25.6 \%$ were college graduates (U.S. Bureau of the Census, 2002). In contrast, among heads of household in families receiving child care subsidies in April 2001, only $52 \%$ had a high school education and only $23 \%$ had some education beyond high school.

\section{Child Care Policy Changes}

We first describe RI's child care subsidy program prior to reform. Next we discuss the changes in policies that occurred as part of the reform program. Finally, we present a description of the use of child care subsidies by various types of families.

\section{The Child Care Subsidy Program Prior to Reform}

Prior to reform, RI's child care subsidy program, like the child care subsidy programs in other states, gave preferential treatment for child care subsidies to cash assistance recipients 
when funds were not adequate to provide subsidies for all eligible families. Cash assistance recipients were entitled to child care subsidies if they were working or participating in the JOBS program. Under the Transitional Child Care program (TCC), working former cash recipients were also entitled to receive child care subsidies for one year after leaving cash assistance. In practice, in RI such families received child care subsidies as long as they were working, income eligible and had an age-eligible child. Other families with incomes below $185 \%$ of the Federal Poverty Level (FPL) were also eligible for child care subsidies under CCDBG, but they only received subsidies if funds were available. ${ }^{3}$

\section{Policy Changes as a Result of the Reforms}

In May 1997, as part of its welfare reform, RI made child care subsidies an entitlement for all families with incomes up to $185 \%$ of the FPL. ${ }^{4}$ This major reform guaranteed availability of subsidized child care to all income-eligible working families with children up to age 13 , regardless of whether or not they were receiving cash assistance. Families with age-eligible children receiving welfare would have to be working or enrolled in approved activities to qualify for child care subsidies. In deciding to guarantee child care, RI made the decision to provide State funding when federal funding was not sufficient to serve all eligible families. ${ }^{5}$

In January 1998, for the first time since August 1994, RI increased the rates it paid to formal child care providers (called reimbursement rates) under the child care subsidy program. The increase in reimbursement rates for full-time child care ranged from $12 \%$ (for infant and toddler care in family child care homes) to $22 \%$ (for pre-school care in family child care homes).

\footnotetext{
${ }^{3}$ Although there was no entitlement to subsidized child care in RI prior to welfare reform, RI always had eligibility for working families up to $185 \%$, always invested state money in its child care program (not just CCDBG funds), and didn't impose the 12 month transitional time constraints other states imposed (only an employment and income constraint). However, prior to welfare reform there was no entitlement to child care in RI and, thus, occasionally there were wait lists (e.g., 1994), and some people could not access child care subsidies who otherwise would have been eligible. During our entire study period, the State did not have a waiting list.

${ }^{4}$ In 1997 the poverty threshold for a family of 3 in the 48 contiguous states and D.C. was $\$ 13,330.185 \%$ of the FPL in 1997 was $\$ 24,660$.
} 
The major reform of RI's child care subsidy program, referred to as Starting RIght, began in January 1999 . Under this program the State increased from $185 \%$ to $200 \%$ of the FPL the maximum income that families could receive to be eligible for child care subsidies, and it increased from 12 to 14 years the maximum child age to qualify for child care subsidies. ${ }^{6}$

In January 1999, the State also increased reimbursement rates. Reimbursement rates for formal child care providers were increased between $4 \%$ (for before-school care) and $14 \%$ (for care of a preschooler in family child care homes).

A second wave of child care policy changes occurred in July 1999. At that time, the State increased from $200 \%$ to $225 \%$ of the FPL the maximum allowable family income to qualify for the child care subsidy entitlement, and it increased to 15 the maximum child age to receive a child care subsidy. Reimbursement rates for formal care were also increased in July 1999, with increases ranging from 7\% (for infant and toddler care in family child care homes) to $13 \%$ (for preschool care in family child care homes).

In January 2000, Rhode Island implemented the State requirement that reimbursement rates for formal care be set at the $75^{\text {th }}$ percentile of the most recently available survey of child care prices (known as a market rate survey). ${ }^{7}$ The implementation of this requirement resulted in large increases in reimbursement rates and considerably increased for providers the attractiveness of participating in the child care subsidy program. The January 2000 rates were set at the $75^{\text {th }}$ percentile of market prices found in the 1998 market rate survey. This resulted in

5 Even before the recent economic downturn, most states had waiting lists for child care subsidies (Collins, et al., 2000). Under the Federal welfare reform legislation, child care subsidies are no longer an entitlement.

${ }^{6}$ In 1999 the poverty threshold for a family of 3 in the 48 contiguous states and D.C. was $\$ 13,880.200 \%$ of the FPL in 1999 was $\$ 27,760$. The federal child care subsidy program allows children that are not disabled to be served only up to the age of 13 . Rhode Island expanded age-eligibility using State funds.

${ }^{7}$ Federal regulations require that states reimbursement rates be set so as to provide "equal access" to care for subsidized children. States that set rates at the $75^{\text {th }}$ percentile of prices found in a market rate survey that is not more than two years old are presumed to have provided equal access. In general, setting the reimbursement rate at the $75^{\text {th }}$ percentile means that the state can pay $75 \%$ of providers their usual and customary price. The RI State Legislature went further and required that a market rate survey be conducted every two years and that rates be adjusted to reflect survey results. 
rate increases ranging from $19 \%$ (for the care of infant and toddlers in family child care homes)

to $78 \%$ (for the before-school care of school-age children in child care centers). ${ }^{8}$

\section{Description of the Rhode Island Child Care Subsidy Program:}

\section{May 1996-April 2000}

Figure 2 shows substantial growth in the number of families receiving child care subsidies in RI. Between May 1996 and April 2000, the total number of families receiving child care subsidies more than doubled, from just under 4,000 families in May 1996 to just over 8,000 families in April 2001. Reflecting RI's goal of treating all low-income families equally, child care subsidies for income-eligible low-income families not currently receiving cash assistance (i.e., families never on cash or formerly on cash) grew most rapidly during this period, from slightly less than 1,500 families in May 1996 to slightly more than 5,000 families in April 2000, a 3 1/2-fold increase. Among income-eligible families receiving child care subsidies, the growth was most dramatic among those who had never received cash assistance, as opposed to those who had. ${ }^{9}$ Between May 1996 and April 2000, the number of families receiving both cash assistance and child care subsidies grew more slowly, by less than $50 \% .^{10}$

Figure 2 also shows the phase-out of the Transitional Child Care (TCC) program. Under its May 1997 welfare reform program, RI abolished and gradually phased out the TCC subsidy

\footnotetext{
${ }^{8}$ To give an example of provider reimbursement rates paid after the January 2000 increases, licensed centers were paid $\$ 160$ per week for infant/toddler care and $\$ 140$ per week for preschool care; certified family child care homes were paid $\$ 125$ per week for full-time care of infants, toddlers, and preschoolers; licensed before-school facilities were paid $\$ 50$ per week and licensed after-school facilities were paid $\$ 67$ per week.

${ }^{9}$ To determine if a family had been on cash between May 1996 and April 2001, we searched all AFDC/FIP administrative files for the period. Families were classified as "never-on-cash" if they did not appear at any time between May 1996 and April 2001 in the AFDC/FIP records. A family was declared a "former" recipient if it appeared at some point in the May 1996 to April 2001 AFDC/FIP administrative records. Note that a family might receive cash assistance after they received child care subsidies rather than before. That is, the correct name for this group might be low-income families that are receiving child care subsidies this month that were formerly or later on cash assistance.

${ }^{10}$ Rhode Island experienced a slower decline in welfare caseloads during the study period than many other states. Further, Rhode Island did not pursue diversion from welfare to the extent that most other states did. Thus, the relatively more rapid increase in the income-eligible population was only partially the indirect effect of welfare reform. The increases in income-eligibility and the increase in provider recruitment due to the increase in
} 
program, as all working income-eligible families with an age-eligible child became entitled to child care subsidies, regardless of their welfare status.

Figure 3 shows the take-up rate for child care subsidies for single-parent current and former cash assistance recipients in RI, from Q2 of 1996 to Q2 of $2000 .{ }^{11}$ Note that the universe of families studied for the take-up rate analyses is narrower. We do not include families that never received cash assistance. Although we have data on families never on cash who are receiving child care subsidies, we are unable to analyze the take-up rate for such families because we are unable to estimate the eligible population. ${ }^{12}$

\section{The Model}

We model the probability that low-income single mothers will be in one of the eight statuses depicted in Figure 1 as depending upon their relative well being within each status and upon the rules, requirements and other policies of the cash assistance program and of the child care subsidy program. ${ }^{13}$ Our model builds on the work of Anderson and Meyer (1997) and Heckman, LaLonde and Smith (1999).

As can be seen in Figure 1, single parents are eligible for child care subsidies in statuses 1 through 6, and they are not eligible for subsidies in statuses 7 and 8 . At the top of Figure 1, single mothers are split into two groups: (1) those that works 20 or more hours per week and

reimbursement rates also played an important role. See Appendix A for a detailed discussion of Rhode Island's welfare reform.

${ }^{11}$ The change in period of study and from monthly to quarterly data was dictated by our need to use UI data to determine eligibility. UI data are only available quarterly.

12 See Giannarelli, et al. (2001) for a discussion of the difficulties of estimating the number of families eligible for child care subsidies. Despite these difficulties, these estimates are being made by ASPE (HHS) in ccoperation with Julie Isaacs. During an average month between April and September 1998, HHS estimates that $26 \%$ of RI's eligible children received CCDF-funded subsidies. This is a lower bound estimate of the take-up rate in RI for at least two reasons. First, Rhode Island uses substantial amounts of state funds to provide child care subsidies. Second, the 1998 HHS estimates do not take into account the fact that low-income families must be working 20 or more hours per week to be eligible for subsidies. See Witte and Queralt (2002) for a recent discussion of take-up rates.

13 To simplify Figure 1, we do not show two possible transition states. Specifically, due to transition rules, we find some families with child care subsidies that are working less than 20 hours and that are (1) on cash assistance but in no approved activity or (2) that are not on cash assistance. Because there are a large enough number of families in these two transition states, we include them in our model. 
(2) those that do not work or work less than 20 hours per week. ${ }^{14}$ Figure 1 splits each of these two groups into subgroups depending on whether or not they receive cash assistance..$^{15}$ The subgroup that includes those that do not work or that work less than 20 hours per week and receive cash assistance branches out into two subgroups: those that participate in activities that make them eligible for child care subsidies (e.g., education, training, Job Club) and those that do not participate in such activities. ${ }^{16}$ The subgroup that works 20 or more hours per week is also split into two subgroups: those who receive cash assistance and those that do not. The final branches in Figure 1 split parents eligible for child care subsidies (i.e., those receiving cash assistance and participating in an approved activity such as education or training, those receiving cash assistance and working 20 or more hours per week, and those not receiving cash assistance but working 20 or more hours per week) into groups that use child care subsidies and groups that do not. This yields the six statuses (statuses 1-6 in Figure 3) in which we are primarily interested.

Under our model, single mothers will select the status (among the 8 statuses depicted in Figure 1) that they perceive will yield the highest level of well being (including the well being of their children) subject to the constraints of policies of the cash assistance and subsidized child care programs and subject to conditions in the local labor market and child care market. Eligible single moms will participate in the cash assistance and child care subsidy programs if the benefits of doing so exceed the costs (including transaction costs and stigma), subject to the information available to them and depending on their initiative. In other words, we see potential social welfare recipients as choosing to receive cash assistance and/or a child care

\footnotetext{
${ }^{14}$ Working single parents are required to work 20 or more hours per week to be eligible for child care subsidies in RI.

${ }^{15}$ No family in RI reached the maximum time limit for receipt of cash assistance during our study period, so none of our study participants who were not receiving cash were not on cash due to time limits.

${ }^{16}$ Beginning in May 1997, an increasing proportion of cash assistance recipients were required to participate in activities if they were not working at least 20 hours per week.
} 
subsidy if they think that by using these social benefits they can maximize the expected present value of their utility over the expected duration of program participation.

Formally speaking, we see single moms as comparing, over the expected duration of program benefit receipt (denoted d), the utility (denoted $\mathrm{U}$ ) they expect to receive without program participation versus the utility they expect to receive with participation. We assume that single mothers' utility depends upon earned income (E) net of child care and other costs of working (wc), the level of cash assistance payments and the policies of the cash assistance program (CA), how many leisure hours they have $(\mathrm{I})$ and the well being of their children (C). Individuals evaluate their utility using the information available, denoted I. The expected utility in status i (where i goes from 1 to 8 ) over the expected length of time that they believe they will be in this status (denoted d) is ${ }^{17}$

$$
\sum_{t=1}^{d} U\left(E_{t}^{i}-w c_{t}^{i}, C A_{t}^{i}, l_{t}^{i}, C_{t}^{i}\right) \mid I
$$

Single mothers will choose the status that maximizes their expected utility subject to program rules (e.g., eligibility requirements for child care subsidies) and the opportunities available in the local labor market and child care markets.

To illustrate (see Figure 1), consider the choice between status 3 (i.e., working 20 hours or more and receiving cash assistance and a child care subsidy) and status 4 (i.e., working 20 hours or more and receiving cash assistance but no child care subsidy). Let the benefits of receiving a subsidy to cover child care expenses potentially be of both monetary and nonmonetary form. (Net monetary benefits, ${ }^{18}$ denoted b, may decrease the costs of working. A non-monetary benefit may increase the well being of the children; for example, the parent may

\footnotetext{
${ }^{17}$ Note that to keep the model simple we do not discount benefits and costs that occur in the future. Incorporation of a discount rate, as done in Anderson and Meyer (1997), would not be difficult. However, given the generally short duration of child care subsidy, we do not believe that incorporation of a discount rate merits the added complexity (Meyers, et al., 2001).

${ }^{18}$ Net benefit is the decrease in child care costs net of any required payment by the parent.
} 
consider child well being $(C)$ to be higher when the child is in subsidized child care than when the child is in unsubsidized care.) The transaction costs/stigma of subsidy or cash assistance receipt, denoted $c_{s}$ and $c_{c a}$, may also be either monetary, denoted $c^{m}$, or non-monetary, denoted $\mathrm{c}^{\mathrm{nm}}$. The utility of being in status 3 is

$$
\sum_{t=1}^{d} U\left(\left(E_{t}^{3}-w c_{t}^{3}\right),\left(C A_{t}^{3}-c_{c a, t}^{3, m}\right),\left(l_{i}^{3}-c_{c a, t}^{3, n m}\right), C_{t}^{3}\right) \mid I
$$

and the utility of being in status 4 is

$$
\sum_{t=1}^{d} U\left(E_{t}^{4}-\left(w c_{t}^{4}-\left(b_{t}^{4}-c_{s, t}^{4, m}\right)\right),\left(C A_{t}^{4}-c_{c a, t}^{4, m}\right),\left(l_{i}^{4}-c_{s, t}^{4, n m}-c_{c a, t}^{4, n m}\right), C_{t}^{4}\right) \mid I .
$$

The working single-mother cash assistance recipient will use a child care subsidy if

$$
\begin{aligned}
& \sum_{t=1}^{d} U\left(E_{t}^{4}-\left(w c_{t}^{4}-\left(b_{t}^{4}-c_{s, t}^{4, m}\right)\right),\left(C A_{t}^{4}-c_{c a, t}^{4, m}\right),\left(l_{i}^{4}-c_{s, t}^{4, n m}-c_{c a, t}^{4, n m}\right), C_{t}^{4}\right) \mid I \\
& >\sum_{t=1}^{d} U\left(\left(E_{t}^{3}-w c_{t}^{3}\right),\left(C A_{t}^{3}-c_{c a, t}^{3, m}\right),\left(l_{i}^{3}-c_{c a, t}^{3, n m}\right), C_{t}^{3}\right) \mid I .
\end{aligned}
$$

Next consider the likely impacts of RI's child care eligibility expansions and increases in provider reimbursement rates. The age-eligibility expansions affect the choices available to all families with children between the ages of 13 and 16 . These expansions should increase the probabilities of being in statuses 1,3 and 5, relative to other statuses. The entitlement to child care and the income-eligibility expansions increase the desirability of working more hours per week and having higher incomes (e.g., being in status 5 in Figure 1). These changes should have no effect on the probability of being in statuses 1 or 3 since families in these statuses have incomes that do not exceed $110 \%$ of the FPL and were entitled to child care subsidies before the policy changes.

Increases in provider reimbursement rates will have both a direct and an indirect effect on families' choices. By increasing the monetary rewards associated with participating in the child care subsidy program, increases in reimbursement rates are likely to directly increase the 
number of providers willing to accept child care subsidies. The indirect effect of increases in reimbursement rates is to increase eligible family participation in the subsidized child care program. This is done by increasing provider motivation to provide information to low-income families about changes in child care policies that affect their eligibility or potential benefits and to recruit them into the subsidized child care program. ${ }^{19}$

During the early part of our study period, rates were too low to attract a broad spectrum of providers to the child care subsidy program, and knowledge about the program by families not receiving cash assistance was limited. However, the rate increases that occurred during the study period greatly increased the willingness of providers to care for subsidized children. By the end of the study period, the majority of formal providers cared for at least some subsidized children, and knowledge of the subsidy program among low-income families was substantially better. We would expect this increase in information regarding the subsidy program and increased recruitment effort on the part of providers to increase the probability that families no longer receiving cash assistance would work 20 or more hours per week and use child care subsidies (i.e., increase the probability of families moving into status 5 of Figure 1).

Overall, our model suggests that the largest impact of RI's reform of its child care subsidy program should be to increase the probability that families would be in status 5 of Figure 1 (i.e., off cash assistance, using a child care subsidy and working 20 or more hours per week). We would expect positive, but smaller impacts, on the probability that families on cash assistance and eligible for subsidies would use subsidies (i.e. smaller increases in the probabilities of being in statuses 1 or 3 of Figure 1$){ }^{20}$

\footnotetext{
${ }^{19}$ The administrators of the child care subsidy program in RI believe that formal child care providers provided income-eligible families with most of the information about changes in the child care program.

${ }^{20}$ As noted earlier in this section, welfare reform will also impact the likelihood that low-income families will be in various statuses. Appendix A provides a description of Rhode Island's welfare reform. RI's welfare reform
} 


\section{The Data}

To estimate the impacts of the child care policy reforms in RI on current and former cash assistance recipients, we construct a longitudinal database for the period May 1996 to April 2000. The database includes all female-headed, single-parent households (i.e., households with no other responsible adult) between the ages of 18 and 60 (i.e., of working age) that at some time between May 1996 and April 2000 received cash assistance. ${ }^{21}$ Single-parent households made up, on average, approximately $90 \%$ of the total number of households receiving child care subsidies between May 1996 and April $2001 .^{22}$ Because the UI data is only available on a quarterly basis, our analysis database is quarterly.

The longitudinal database contains: (1) RI Department of Human Services (DHS) administrative data for the child care subsidy program, (2) RI DHS administrative data for the cash assistance program, (3) employment information from the administrative records of the Unemployment Insurance (UI) program, ${ }^{23}$ (4) Program Information Reports for all Head Start programs in RI, (5) information on Kindergarten programs for all townships in RI, (6) information on the availability of formal child care in all RI townships and (7) monthly information on employment growth for all townships.

should increase the probability that low-income families would be working 20 or more hours per week and increase the probability that cash assistance recipients would be involved in some activity.

${ }^{21}$ We exclude cash assistance families that are always exempt from activity and work requirement since such families are very unlikely to be in most of the statuses we consider.

${ }^{22}$ There is no direct indicator of family type in the child care subsidy files. To estimate, the proportion of active AFDC/FIP recipients that had more than one adult, we relied on the reports about amount of time spent in AFDC/FIP activities. If there was more than one activity reported, we assumed that there were two adults in the household. Two activities were reported for $10 \%$ of active AFDC/FIP recipients receiving child care subsidies between May 1996 and April 2001. Note that this probably overestimates the number of two-adult households since some AFDC/FIP recipients participate in more than one activity. For working households, we have a direct measure of the presence of another working adult. Between May 1996 and April 2001, 12\% of working households receiving child care subsidies had two earners.

${ }^{23}$ We received no personal identifiers, such as names, street addresses or social security numbers. The RI DHS did all data matching, sending the data to us only with person numbers and case numbers as unique identifiers. 


\section{Empirical Specification}

We model the probability that a single mother in our sample will be in one of the eight statuses represented in Figure 1 (or in one of the two transitional statuses described in footnote 7). The probability of a single mother being in a particular status depends on the factors identified in the above model, including: (1) the level of earnings net of the costs of working, (2) the dollar value of cash assistance net of monetary transaction/stigma costs of receiving cash assistance, (3) the value of leisure time net of non-monetary costs (e.g., the disapproval of friends, the time costs of applying for and using cash assistance and child care subsidies) and (4) the well being of the children.

We estimate the reduced-form of this model. That is, we include only variables that are either exogenously determined or predetermined. These variables will be related to the underlying theoretical variables, but they will not be determined simultaneously with the probability that a single mother is in one of the eight statuses. Thus, for example, we include education rather than earnings.

Table 1 provides descriptive statistics for the variables we use. They consist of human capital and socio-demographic variables, variables that reflect the availability of child/youth care and education at the beginning of our study period (1996) ${ }_{r}{ }^{24}$ variables that reflect local labor market condition that vary both across communities and across quarters, fixed effects for community of residence when first observed and an unstructured time trend. The unstructured, non-parametric representation of time will reflect time-varying changes that are not incorporated in variables explicitly included in the empirical model. These changes will include changes in the cash assistance program, the expansion of age and income eligibility for child care subsidies and the increases in reimbursement rates for child care subsidies. 
Our human capital and socio-demographic variables include: (1) level of education of the single mother, (2) health/disability status variables for all family members, (3) age variables for children structured to reflect differences in child care costs, (4) variables reflecting race/ethnicity of the parent, (5) household size, (6) the citizenship status of the parent, (7) the number of children in the household who are eligible for child care subsidies and (8) the fraction of subsidy-eligible children of various ages in the household.

All human capital and socio-demographic variables, except age and disability status, reflect the characteristics of the family when first observed. We do not update family characteristics, other than age and disability status, because of their potential endogeneity. We allow age and disability status to vary for members of the household that were present when the household was first observed. We do not include variables that reflect the entry of new members (e.g., a new baby) to the household because of the potential endogeneity of family structure and fertility.

Note that we have included separate variables for the children in the household, such as the number of children eligible for child care subsidies, the age of the youngest child and the number of children of middle-school and secondary-school age. The number of subsidy eligible children is related to the potential benefits of receiving child care subsidies. Children of middleschool and secondary-school age may provide care for younger siblings. We also include the fraction of subsidy-eligible children that are: (1) infants, (2) toddlers, (3) preschoolers and (4) eligible for kindergarten. The suppressed category is school-age children. Note that child care costs and, hence, the potential benefits of using a child care subsidy decrease as children become older.

\footnotetext{
${ }^{24}$ We use this predetermined variable rather than the contemporaneous availability of early care and education because the contemporaneous availability of early care and education will be determined simultaneously with the probability that single mothers are in one of the 8 statuses.
} 
Our vector of variables related to the availability/accessibility of child care and early education includes the number of full-time preschool center slots per 100 children under age 5 in the township in 1996 (the beginning of our study period), the number of family child care slots per 100 children ages 0-13 in the township in 1996 and the number of school-age center and school-based slots per 100 school-age children in the township in 1996. Also included in this vector are the proportion of eligible children enrolled in part-day and full-day kindergarten ${ }^{25}$ in the township of residence, as well as the proportion of eligible three- and four-year-olds enrolled in Head Start in the township of residence in each of the years of our study. While we hold the availability of formal early care and education at its 1996 level, we allow the availability of kindergarten and Head Start to vary over the study period. We do this because we believe that both the local school districts' decisions regarding the number of part-day and full-day kindergarten slots to fund and the federal government's decisions regarding Head Start grant funding ${ }^{26}$ can reasonably be assumed to be exogenous to the decisions concerning employment, cash assistance and subsidized child care of low-income single mothers in our sample.

In the analysis, we interact the availability of various kinds of early care and education with the fraction of children in the family that might use the particular type of care or education. We do this to reflect how well the child care needs of the family might be served by the particular type of care. For example, we multiply the fraction of eligible children served in full-day kindergarten programs by the proportion of the children in the family eligible for

\footnotetext{
${ }^{25}$ While all RI townships have some part-day and/or some full-day kindergarten available, few townships provide services to all kindergarten eligible children. The proportion of kindergarten eligible children served in part day programs ranges from $0 \%$ to $100 \%$ of eligible children across townships with a median $67 \%$ percent of eligible children served in part day kindergarten programs. The proportion of kindergarten eligible children served in full day programs also ranges from $0 \%$ to $100 \%$ of eligible children across townships, but with a median of only $14 \%$ percent of eligible children served in full day kindergarten programs.

${ }^{26}$ Head Start has been in existence since the 1960s, and most Head Start providers have received federal grants for the last 20 years.
} 
kindergarten. ${ }^{27}$ Since kindergarten is only available during the school year, we set to zero the fraction of children served in kindergarten for the summer months.

Consider two different families to get an idea of how the above-mentioned variables operate. The first family has only one child, and the child is eligible for kindergarten. The family lives in a township that provides full-day kindergarten for all eligible children. The second family has three children. One of the children is kindergarten eligible. The family lives in a township that provides part-day kindergarten to $60 \%$ of eligible children. Kindergarten has the potential of serving a substantial portion of the child care needs of the first family during the school year, while the child care needs of the second family would be much less adequately served by the kindergarten services available to them.

Because of the many changes that occurred during our study period, we impose no structure on the pattern of change over time. Instead, we create a separate binary variable for each quarter. This non-parametric representation of time allows each quarter to have a distinct impact on the probabilities that the single mothers in our sample will be in one of the eight statuses. We interpret the coefficients on the quarterly binaries in light of our knowledge of the pattern of policy and administrative changes that occurred during the study period.

To control for local labor market conditions, we include the average monthly change in employment, by township, for each quarter of our study. Finally, we control for community characteristics by including a series of community-specific binaries. Note that the community binary for each family is set at the time that the family is first observed. We do not update the residential community of the families, as families move, because of the potential endogeneity of mobility.

\footnotetext{
${ }^{27}$ Children are eligible for kindergarten in Rhode Island if they are 5 years old by December 31 .
} 
To summarize, the probability that a single mother in our sample will be in a given status depends upon the factors described above and listed in Table 1. These exogenous factors are denoted $\mathrm{x}$. We estimate a multinomial logit model for the probability that a single mother in our sample will be in each of the eight statuses (Green, 2003; Wooldridge, 2002). Under this model the probability that a single mother will be in a particular status, say status $j$, is:

$$
\text { (1) } P(y=j / x)=\frac{\exp \left(x \beta_{j}\right)}{1+\sum_{h=1}^{9} \exp \left(x \beta_{h}\right)}
$$

where $\mathrm{j}=1, \ldots, 9$ (the statuses depicted in Figure 1 and described in footnote 7 ) and $\beta_{j}$ is a $\mathrm{kx}$ 1 vector of parameters to be estimated. ${ }^{28}$

Since we observe families over time, we are able to control for unobservable familyspecific attributes, as well as for observable attributes. To account for these unobservable family specific effects, we allow for separate error variances for each family. ${ }^{29}$

\section{Estimated Changes in the Use of Cash Assistance and Employment}

Figure 4 provides the estimated probabilities that a typical parent in our sample (one with median characteristics $)^{30}$ will be: (1) working 20 hours or more per week, (2) working less than 20 hours per week, receiving cash assistance, not enrolled in an approved activity and not receiving a child care subsidy, (3) working less than 20 hours per week, not receiving cash assistance and not receiving a child care subsidy and (4) working less than 20 hours per week,

\footnotetext{
${ }^{28}$ Because the probability of all possible statuses must add up to 1 , the probability that a current or former cash assistance recipient will be in the base status is 1 over the denominator of equation (1).

${ }^{29}$ See Greene (2003) or Wooldridge (2002) for more detailed discussions of using longitudinal data to control for unobservable family-specific effects. Note that failure to control for unobservable family specific effects will lead to inconsistent parameter estimates.

30 This median family has a 30-year-old white English-speaking head, two subsidy-eligible children and no other person in the household between the ages of 18 and 60. The youngest child in the household is 4 years old and the household has no teenager. The family lived in a community with an employment growth rate of $2.9 \%$ per year when first observed. In 1996 the community had 22 full-time center slots per 100 children under age 5, 7 school-age slots per 100 school-age children, and 3 family child care slots per 100 children ages 0-13.
} 
receiving cash assistance and enrolled in an approved activity. This graph shows two major changes during the study period: a) a rapid decline in the probability that the typical parent in our sample would be receiving cash assistance and neither working nor in some other approved activity; and b) a rapid increase in the probability that the typical parent in our sample would be working 20 hours or more per week.

To be more specific, Figure 4 shows that the estimated probability that the typical parent in our sample would be on cash and neither working nor in some other approved activity declined by almost 50\% during the study period (from a probability of 47\% in Q2 of 1996 to $25 \%$ in Q2 of 2000). During the same period, the probability that the typical parent in our sample would be working 20 or more hours per week more than tripled (from a probability of $7 \%$ in Q2 of 1996 to $22 \%$ in Q2 of 2000). Put somewhat differently, we estimate that the typical parent in our sample was almost 7 times more likely in Q2 of 1996 than in Q2 of 2000 to be receiving cash, working less than 20 hours per week, and not participating in some other approved activity. In contrast, by Q2 of 2000, she was almost as likely to be working 20 or more hours per week as to be receiving cash and neither working nor participating in some other approved activity. Because we control for the growth in employment at the township level, we believe that these changes are mainly the result of the combined impacts of RI welfare reform and the reform of its early care and education subsidy program. However, some portion of the increase in employment may be related to economic factors unrelated to employment growth.

\section{Estimated Changes Due to Child Care Policy Reforms}

In this section we attempt to separate the impact of changes in the child care subsidy program from the changes related to welfare reform in RI on: (1) the take-up rate for child care 
subsidies and (2) the probability of employment and receipt of cash assistance. We employ two different strategies to do this.

\section{Estimated Changes in Use of Child Care Subsidies Associated with Child Care Policy Reforms}

To estimate the impact of the child care policy changes on the use of child care subsidies, we analyze the estimated relative probabilities (i.e., the odds) that a child care subsidy-eligible family will use such subsidies in different quarters of the study period, holding constant all the other factors in the model, including local labor market conditions. We expect the expansions in eligibility for child care subsidies and the increases in provider reimbursement rates for formal care to increase the relative probabilities of using subsidies when eligible (e.g., increase the probability of being in status 1 relative to status 2, in status 3 relative to status 4 and in status 5 relative to status 6).

Eligibility for child care subsidies will be affected by both welfare reform and the reform of the child care subsidy system. However, in RI, the probability of taking child care subsidies, when an individual is eligible, should be impacted primarily by the policies of the child care subsidy system, not by welfare reform. ${ }^{31}$ In this section, we are seeking to discern whether or not there was a significant increase in the probability that an eligible family would use child care subsidies (i.e., an increase in the take up rate for child care subsidies) as a result of the child care policy reforms.

For each quarter of the study period (listed in column 1 of Table 2), Table 2 gives, in column 2 , the percentage change $(\Delta)$ in the estimated odds that a single-parent family in our study working less than 20 hours, enrolled in an approved activity and receiving cash assistance

${ }^{31}$ This is because RI's welfare reform was not a work-first reform and did not have welfare diversion as a major element. See Appendix A. In states with work-first welfare reform programs and where diversion programs play a major role, welfare reform is likely to impact the proportion of eligible families that use child care subsidies. The effect would result mainly from improved information provided by work-first and diversion counselors. 
will receive a child care subsidy (i.e., will be in Status 1 rather than in Status 2), relative to the first quarter of the study (the baseline period, Q2 of 1996). These estimates control for all the variables listed in Table 1. A positive number indicates an increase in the likelihood that a family will use a child care subsidy, and a negative number indicates a decrease. Column 3 of Table 2 gives the probability (P-value) that the percentage change $(\Delta)$ in the odds for each quarter is insignificantly different from the odds in the baseline quarter--Q2 of 1996 (i.e., 0\% change).

The remaining columns in Table 2 present the same percentage change in odds and Pvalues of receiving a child care subsidy. Column 4 presents the change in odds of receiving a child care subsidy for single-parent families working 20 or more hours per week and receiving cash assistance (Status 3, rather than Status 4). Column 5 provides P-values (i.e., probability that such change would have occurred by chance). Column 6 presents the change in odds of receiving a child care subsidy for single-parent families working 20 or more hours per week and not receiving cash assistance (Status 5, rather than Status 6). Column 7 presents the P-values.

As can be seen in Table 2 (columns 2 and 3) the odds of being in Status 1 (i.e., cash assistance recipients enrolled in approved activities and working less than 20 hours per week using a child care subsidy) rather than in Status 2 in RI increased significantly (relative to the odds of using a child care subsidy, for the same group, in Q2 of 1996) throughout the study period, holding constant all other factors listed in Table 1. Table 2 shows that, during the quarters under the AFDC program, the odds that those in this group would have a child care subsidy increased on average by approximately $20 \%$ over the odds in the base period (Q2 of 1996). For this group, during the first year of RI welfare reform (May 1997-April 1998), the odds of using a subsidy (rather than not using one), relative to the baseline period, almost doubled (up to an average of approximately $40 \%$ ). The odds of using a subsidy (rather than 
not) were about 34\% higher than the odds in Q2 of 1996 during the first year of child care policy changes (January 1999 to December 1999). For the last two quarters of the study, the odds were higher than in 1999. However, an analysis of variance on the percentage change in the odds before and after the beginning of major child care policy reforms (i.e., before and after January 1,1999$)$ indicate that, for this group, the child care policy reforms had no significant effect on the odds of using a child care subsidy. This finding is not unexpected since this group was least affected by the child care policy reforms.

As can be seen in columns 4 and 5 of Table 2, during the quarters under AFDC, the odds of being in Status 3 rather than in Status 4 (i.e., participating in the cash assistance program, working 20 or more hours per week and using a child care subsidy) increased significantly only for one quarter (Q3 of 1996), relative to the odds of using a subsidy in Q2 of 1996, the baseline period. During the first year of RI's welfare reform, across all four quarters, the odds of taking child care subsidies for this group were significantly higher--almost $70 \%$ higher--relative to Q2 of 1996. For this group, during the second year of welfare reform, the odds of taking subsidies were almost double the odds of taking a subsidy in Q2 of 1996--an average of $117 \%$ higher. The odds jumped significantly again during the first year of child care policy reforms, to an average of $134 \%$ higher than the odds of taking subsidies in Q2 of 1996 . Analysis of variance indicates that the odds of using a child care subsidy for this eligibility group increased significantly after the child care policy reforms that began in January 1999.

As can be seen in Table 2 (columns 6 and 7), during the quarters of our study under the old AFDC program and during the first year of RI's welfare reform, the estimated odds of being in Status 5 (i.e., not currently receiving cash assistance, working 20 or more hours per week and receiving subsidized child care) rather than in Status 6 were insignificantly different from the odds that they would use subsidies in the base period (Q2 of 1996). Table 2 shows that 
during the second year of welfare reform in RI, which includes the first quarter of child care policy reforms, the odds such eligible working former recipients would be in status 5 (i.e., receiving subsidies), relative to the odds of being in status 6 (i.e., not receiving subsidies), rose rapidly. On average, during the period extending from Q2 of 1998 to Q1 of 1999, the odds of using child care subsidies were $50 \%$ higher than during the base period (Q2 of 1996). This increase in odds, relative to the base period, is significant at any commonly used level of significance (e.g., .001 level). Finally, Table 2 shows that for this eligibility group, the odds of taking child care subsidies continued to rise during the first full year of child care policy reforms to an average of $60 \%$ higher than the base period. During the last quarter of our study, the odds of taking subsidies for this group (80\%) were almost double the odds in the base period. An analysis of variance indicates that the odds that an eligible family in this group would use a child care subsidy were significantly higher after the January 1999 child care policy reforms than before the reforms.

Overall, our results indicate that RI's child care policy reforms significantly increased the likelihood that current and former single-parent welfare families working 20 or more hours per week would use child care subsidies. To be more specific, as can be seen in Table 3, the takeup rate for child care subsidies for all groups increased between the first year of the study (Q2 of 1996 to Q1 of 1997) and the last year (Q3 of 1999 to Q1 of 2000). Table 3 shows that the increase in the take-up rate was greatest for those off cash assistance and working at least 20 hours per week (from $42 \%$ to $58 \%$ ), and the increase was least for those on cash assistance and active but engaged in an activity other than unsupported work (from $47 \%$ to $49 \%$ ).

\section{Estimated Changes in Employment and Welfare Status}




\section{Associated with Child Care Policy Reforms}

To estimate the impact of the child care policy reforms on the probability of leaving welfare and working 20 or more hours per week, we use what is called in the economics literature a difference in differences approach. To implement this approach, we use the quarterly estimates of the probabilities that the typical current or former welfare family will be in statuses 1-6 in Figure 1. See Figure 5 for the estimated probabilities.

We begin by calculating the change (before and after the child care policy reforms, that is, before and after January 1999) in the estimated mean probability of being in each status. This gives us six changes in mean probabilities. See Table 4 for these six changes (i.e., differences) in mean probabilities. These differences control for unobserved within-group differences. As can be seen in Table 4, these differences in mean probabilities range from -.008 (for cash assistance recipients working less than 20 hours per week, enrolled in approved activities and not using child care subsidies) to +.043 (for former recipients working 20 or more hours per week and using child care subsidies).

Attributing these pre-post differences exclusively to the January 1999 child care policy reforms is problematic since some other factor that also changed over time could account for the difference. Such factors might include economic factors other than local labor market conditions (for which we control) and longer-term effects of RI's welfare reform.

To control for such unobserved time-varying effects, for each eligibility group-- (1) those enrolled in approved activities, working less than 20 hours per week and on cash assistance, (2) those working 20 or more hours per week and on cash assistance, (3) those working 20 or more hours per week and not on cash)--, we subtract the before-after difference [i.e., P(After)$\mathrm{P}($ Before $)]$ in estimated mean probabilities for those using subsidies from the before-after difference for those not using subsidies. That is, we take the difference in the before-after 
differences for the subsidized and unsubsidized subgroups within each eligibility grouping. This is our difference in differences estimate of the impact of the child care policy reforms on the probability that the typical current and former cash assistance recipient would work (denoted Diff in Diff in Table 4). See bolded entries in Table 4. These estimates assume that the change in the probability of being in the subsidized versus the unsubsidized group would have been equal if there had been no child care policy reform.

Our results indicate that the main impact of the child care policy reform was to significantly increase the probability that current and former welfare recipients would be working 20 or more hours per week. To be more specific, we estimate that the child care policy reforms significantly increased (by 3.1 percentage points) the mean probability that recipients would be in Status 5 (i.e., not receiving cash assistance, working 20 or more hours per week and receiving child care subsidies) and significantly increased (by approximately 1.2 percentage point) the mean probability that current recipients would be in Status 3 (i.e., receiving cash assistance, working 20 or more hours per week, and receiving a child care subsidy). Assuming that this change in probability is representative for the 29,468 female single-parent working-age households in our sample, we estimate that, during the period ranging from Q1 of 1999 to Q2 of 2000 , the child care policy reforms, on average, resulted in 914 additional families per quarter being in Status 5 (i.e., not receiving cash assistance, working 20 or more hours per week and receiving child care subsidies) and an additional 354 cash assistance recipients per quarter being in Status 3 (i.e., receiving cash assistance, working 20 or more hours per week, and receiving a child care subsidy).

As can be seen in Figure 5, the impact of the child care policy reforms increased over time, particularly for former recipients. This is not unexpected. The eligibility expansions would have become known gradually and the impacts of formal providers' recruitment of new subsidy 
recipients would have taken time to play out. In the final quarter of our study ( $1 \frac{1 / 2}{2}$ years after the January 1999 reforms and $1 / 2$ year after the January 2000 reimbursement rate increases), we estimate that the typical family head in our sample was 5.7 percentage points more likely to be in Status 5 (i.e., not receiving cash assistance, working 20 or more hours per week and receiving child care subsidies) as a result of the child care policy reforms and that current recipients were 1.75 percentage point (for convenience called $1.75 \%$ ) more likely to be in Status 3 (i.e., receiving cash assistance, working 20 or more hours per week, and receiving a child care subsidy). This implies that in Q2 of 2000, 1680 additional families per quarter were in Status 5 (i.e., not receiving cash assistance, working 20 or more hours per week and receiving child care subsidies) and 516 additional current cash recipients per quarter were in Status 3 (i.e., receiving cash assistance, working 20 or more hours per week, and receiving a child care subsidy). We suspect that the total impact of the child care policy reforms had not yet fully played out by the end of our study period and that the long term impact might well be larger than the impact we estimate for Q2 of 2000 (the last month for which we have data).

Our interpretation of these difference in differences as representative of the impact of the child care policy changes relies on the assumption that, in the absence of the child care policy reforms, the difference between the estimated mean probability "before" and "after" for families in a given eligibility group (Status 1 versus Status 2, status 3 versus Status 4, or Status 5 versus Status 6) would have been the same. For example, for the group of child care subsidy eligible families working 20 or more hours per week and not receiving cash assistance (statuses 5 and 6), this method assumes that the difference in the estimated mean probability before and after for families in Status 5 and in Status 6 would have been the same if there had been no change in child care policy. 
It should be noted that the estimates reported in this paper do not include the impacts of the substantial increase in the supply of formal child care that resulted from the rapid increase in reimbursement rates nor do they include the impact of the policy changes on lowincome families that never received cash assistance.

\section{Summary and Conclusions}

Our work indicates that the child care policy changes associated with Rhode Island's reform of its child care subsidy program significantly increased the likelihood that current and former welfare recipients would use child care subsidies and would work 20 or more hours per week. In addition, we find evidence that these policy changes encouraged cash recipients to leave welfare for work.

Our results indicate that the impacts of Rhode Island's reform of its child care subsidy program are different for different client eligibility groups: (1) cash assistance program recipients working less than 20 hours per week and enrolled in approved activities such as education or training, (2) cash assistance program recipients working 20 or more hours per week, and (3) former cash assistance program recipients working 20 or more hours per week.

Overall, the impacts of the child care policy reforms were strongest for those who left the cash assistance program and were working 20 or more hours per week and least dramatic for cash recipients working less than 20 hours per week who were enrolled in some other approved activity. This is consistent with our model, since both the eligibility expansions and the increased efforts of providers to recruit eligible child care subsidy recipients as a result of the reforms should have had its greatest impact on families that were not receiving cash assistance.

Some child care policy changes (e.g., the entitlement to child care subsidies and the expansion of income and age eligibility for subsidies) directly impacted the likelihood that families would use a child care subsidy. Other policy changes (e.g., the increase in provider 
reimbursement rates) affected families both directly (i.e., by increasing the availability of formal child care) and indirectly (i.e., by more active provider recruitment efforts directed at eligible families). Our estimates of the effects of the reimbursement rate increases are only for the indirect impacts. Both because our estimates do not reflect the impacts of the increased availability of care and because our study ends two quarters after the largest increase in reimbursement rates, they should be considered lower bound estimates of the magnitude of the impact of the child care policy changes on current and former cash assistance program recipients. The estimates reported in this paper do not consider the impact of the policy changes on low-income families that never participated in the cash assistance program.

To obtain estimates of the effects of the Rhode Island changes in child care policy on the likelihood that an eligible family would use child care subsidies, we constructed a longitudinal database for the period May 1996 (a year before RI's welfare reform) to April 2000 (a year and a half after the beginning of the major child care policy reforms). This database encompassed information obtained from many sources, including DHS administrative records for families enrolled in the child care subsidy program and currently and formerly enrolled in the cash assistance program, information on their employment record from the administrative records of the Unemployment Insurance (UI) program, and, for all townships in RI, information on the availability of formal child care and early education and on the labor market. We analyze these data using economic modeling and the multinomial logit estimation technique.

Using results of the multinomial logit estimation, we estimate the odds that a family eligible for child care subsidies will use the subsidies in each quarter of our study period. We find that, for eligible families working 20 or more hours per week, the odds that they would use child care subsidies increased markedly and significantly after the January 1999 child care policy reforms. We find no significant increase in the odds of using a child care subsidy for welfare 
families working less than 20 hours per week who were eligible for such subsidies because they were enrolled in some approved activity such as education or training.

We also use the multinomial logit results to predict the probability, for each quarter of our study, that the typical, female-headed, single-parent family in our sample would be in each of the eight statuses depicted in Figure 1. The results indicate that the combined effects of Rhode Island's welfare reform and the reform of its child care subsidy program were to more than triple the probability that a single mother in the sample would be working 20 or more hours per week (i.e., the probability increased from 7\% in Q2 of 1996 to 22\% in Q2 of 2000) and to almost cut in half the probability that a single mother in the sample would be on welfare, working less than 20 hours per week and not enrolled in some other approved activity (i.e., the probability decreased from $47 \%$ in Q2 of 1996 to $25 \%$ in Q2 of 2000). These estimates may either overstate or understate the combined impacts of welfare reform and the child care policy reforms. They may understate the combined effects because some of the impacts of both welfare reform and the child care policy reforms had not yet occurred by the end of our study period. For example, no cash assistance program recipients had exhausted their time limits by the end of the study period. They may either overstate or understate the combined impact of welfare reform and the reform of the child care subsidy program if there was some unobserved economic change (other than employment growth for which we control) or other unobserved time varying change that impacted the probabilities that families would be in various statuses.

To separate the impacts of welfare reform (and other unobserved time varying effects) from the impact of the child care policy reforms, we use a difference in differences approach and the estimated probabilities that the typical sample member would be in one of the eligibility statuses for child care subsidies (i.e., statuses 1-6 in Figure 1). We estimate that the child care policy reforms increased the mean probability that a typical family in the sample would work 20 
or more hours per week and would no longer receive cash assistance by 3.1 percentage point (for convenience we refer to this as 3.1\%). This result is significant at any normal level of statistical significance and controls for both observed and unobserved cross-sectional and timevarying effects. This finding implies that, on average, between the first quarter of 1999 (Q1 of 1999) and the second quarter of 2000 (Q2 of 2000), as a result of the child care policy reforms, almost 1000 additional Rhode Island families per quarter were in Status 5 (i.e., not receiving cash assistance, working 20 or more hours per week and receiving child care subsidies). We estimate that the child care policy reforms also significantly increased the probability that a family receiving cash assistance would work 20 or more hours per week, although the magnitude of the effect is smaller (i.e. 1.2\% increase in probability). This finding implies that, on average, approximately 350 additional Rhode Island welfare families per quarter were in Status 3 (i.e., receiving cash assistance, working 20 or more hours per week, and receiving a child care subsidy).

We find evidence that, as might be expected, the effects of the reform of the child care subsidy program were larger in later periods than immediately after the reforms. In the final quarter of our study, the second quarter of 2000, we estimate that, as a result of the child care policy reforms the typical family head in our sample was $5.7 \%$ more likely to be in Status 5 (i.e., not on cash assistance, working 20 or more hours per week and receiving child care subsidies) and current recipients were $1.75 \%$ more likely to be in Status 3 (i.e., on cash assistance, working 20 or more hours per week, and receiving a child care subsidy). These findings imply that, during Q2 of 2000, approximately 1680 additional RI families were in Status 5 (i.e., not on cash assistance, working 20 or more hours per week and receiving child care subsidies) and 516 additional cash assistance program recipients were in Status 3 (i.e., on cash 
assistance, working 20 or more hours per week, and receiving a child care subsidy) as a result of the child care policy reforms that were instituted.

We find that the child care policy reforms had no significant impact on the probability that a cash assistance program recipient working less than 20 hours and enrolled in other approved activities would use child care subsidies.

The results described above provide empirical evidence that Rhode Island's child care policy reforms served as an important support that allowed low-income families to find employment and to stay off welfare. 


\section{Appendix A}

\section{Rhode Island's Welfare Reform, FIP}

With the passage of the Family Independence Act (FIA), RI began a major revision of its

welfare system. The first stage of the implementation of Rhode Island's welfare reform, called the Family Independence Program (FIP), which was initiated in May 1997, brought about changes in the time allowed on cash support, in the eligibility rules for cash support and in the job placement services provided. The most important of these changes are described below.

\section{Lifetime 60-month Time Limits}

FIP imposes on able adults under the age of 60 a lifetime 60 -month time limit for the receipt of cash supplements. However, the cash assistance clock does not run for FIP families that are: a) exempt for disability of parent or child, b) headed by a minor teen, c) families where the adults are over the age of 59 , or d) families under waiver for domestic violence. Also, the FIP clock does not begin to tick until the family has had an assessment and has an employment plan (this is discussed further on in a separate section).

The FIP 60-month clock does not stop for able adults who are caring for a child, even when the child is under the age of one or for recipients in the last trimester of pregnancy. However, until the child is one year of age, they are exempt from the work requirement. In practice this means that women in their last trimester of pregnancy or parents with infants can choose to participate in an approved activity, but until the child is one year of age they won't be sanctioned if they don't. This exemption is different from the exemptions listed above (e.g., incapacity or age over 59) in that the others are not subject to the 60 -month limit or to the work requirement. In contrast, the clock is ticking and lifetime months are accruing for those with a child under age one during their work-exemption period.

24-Months of Education and Training Activities 
In general, FIP recipients may engage in educational or training activities for a maximum of 24 months "on the clock" after their employment plan is signed, regardless of their demographic profile (i.e., whether they are considered hard-to-serve or job ready). After that period of allowed education or training, non-exempt recipients must work (for pay or without pay) at least twenty hours per week in order to continue to receive benefits (RI State Plan: TANF). Activities counted toward the fulfillment of the work requirement include all those allowed under federal guidelines, in addition to a few that are not. For example, while other states disallow post-secondary education, RI gives this option to improve beneficiaries' chances of longer-term and higher-paying jobs.

Specifically, during the first 24 months of the employment plan recipients are required to fulfill their work requirement by participating in one of the following:

$>20$ hours per week of paid employment (including on-the-job training and subsidized employment);

> 20 hours per week of community work experience;

> Training or work readiness program conducted on the job site and approved by the RI Department of Human Services (DHS);

$>$ During the first six months of eligibility, or longer if necessary, participation in an approved rapid job placement program:

- Supervised individual job search;

- Parents under the age of 20 without a secondary credential may participate on a full-time basis in a program to obtain a high school diploma or its equivalent;

- Parents age 20 or older: 
- Literacy or English as a second language classes if needed;

- Job skills training and/or vocational education;

- Post secondary education that is likely to result in a job with high enough wages to make the family ineligible for cash assistance.

\section{Sanctions}

Cash beneficiaries who do not comply with education/training or work requirements are sanctioned. If a beneficiary does not comply with work requirements, as defined in her/his individual employment plan, the family grant is reduced by the parent's portion of the benefit, with the amount of reduction due to sanction increasing over time if the parent continues to fail to comply. Eventually, when the sanctioned parent's potential lifetime eligibility is exhausted (e.g., after 60 months), the child(ren)'s portion may be entrusted to an agency or individual other than the parent. ${ }^{32}$

\section{Job Placement and Retention}

FIP established a new staff function in 1997, the Employment Placement and Retention Unit. This unit consists of six DHS Social Workers whose principal responsibilities are employment placement and retention as well as troubleshooting for working beneficiaries and employers, bureaucracy problem-solving, job development and replacement, job upgrading, and resolution of child care and transportation issues.

\section{Expansion in Number of Two-Parent Families Eligible for Cash Assistance}

The old AFDC program served few two-parent families because at least one of the parents had to be unemployed or incapacitated in order for the family to qualify. In order to strengthen and support two-parent families, FIP made two-parent families eligible for cash

\footnotetext{
${ }^{32}$ The implementation of multiple-stage sanctions did not occur until the fall of 2001.
} 
assistance based on income (not unemployment or incapacity). This provision has resulted in a significant increase in the number of two-parent households receiving cash assistance, about $6 \%$ of the caseload in April 2000, although single-parent households continue to comprise the majority receiving cash assistance.

Increases in Income Disregards and Elimination of Time Limits on Income Disregards for Working Cash Assistance Beneficiaries

Beginning in May 1997, the amount of the income disregard for cash assistance became more generous than under the previous AFDC program. ${ }^{33}$ FIP also eliminated the AFDC time limits on income disregards. Specifically, under FIP, working families receiving cash assistance are allowed to keep the first $\$ 170$ of monthly earnings without facing any reduction in cash benefits. Beyond the first $\$ 170$ of monthly earnings, and without any time limit, cash benefits are reduced $\$ 1$ for every $\$ 2$ earned (RI State Plan: Temporary Assistance for Needy Families [TANF])..$^{34}$ Thus, under FIP, beneficiaries who are working can exit the cash program gradually as their earnings increase.

\section{Gross Income Test Eliminated}

Another first-stage change in the RI cash assistance program is that the old AFDC gross income test was eliminated. The previous gross income test was the first eligibility standard to which applicants were subjected under the AFDC program. Under AFDC, families with gross income (i.e., income before disregards and other deductions) higher than $185 \%$ of the cash

33 Under AFDC, working cash beneficiaries were allowed to retain the first $\$ 90$ of earnings per month plus $\$ 30$ and one-third of earnings over $\$ 90$. This formula applied for the first four consecutive months of employment. For the next eight consecutive months, recipients were allowed to retain up to $\$ 120$ before there was a reduction of benefits.

34 Under FIP, non-working families receive a cash benefit of $\$ 327$ per month for the first person, $\$ 122$ per month for the second and $\$ 105$ per month for each additional person (i.e., $\$ 6,648$ per year for a family of three). In addition, there were two changes under FIP in the way in which cash benefits are determined. First, low-income families receiving subsidized housing have their cash assistance reduced by $\$ 50$. Second, there have been slight changes in cash benefits for larger families. For example, the monthly cash benefits for a family of 5 with no other income increased from $\$ 710$ to $\$ 715$ and the monthly cash benefit for a family of 15 decreased from $\$ 1542$ to $\$ 1514$. 
grant were declared ineligible. After FIP, the calculation for a working family coming on to the cash program is the same disregard calculation as for going off cash. Both of these provisions have meant that more families can come on cash and stay on cash longer. Thus, under FIP, the cash assistance program has become more of a support program for working families, providing them with a cash supplement to their wages. In fact, beginning in January 2000, working families can continue to receive the wage supplement indefinitely, as long as the parent works at least 30 hours per week (35 hours for a two-parent family) and the family income remains low enough to qualify (RI Department of Human Services, 2001).

\section{Treatment of Minor Teens}

After passage of the Family Independence Act (FIA) in 1996, minor teens were required to live at home or in an adult-supervised setting. In addition, they were required to stay in school. This provision has reduced the number of teens in RI living on their own and getting cash benefits. In 1999 New Opportunity Homes were opened for minor teens with no place else to go. ${ }^{35}$

${ }^{35}$ Since the 1980's minor teenage mothers have been eligible to receive child care (as well as case management and counseling), regardless of income, for the purpose of finishing school. 


\section{REFERENCES}

Anderson, P. M. and Meyer, B. D. (1997). Unemployment Insurance Take-up Rates and the After-Tax Value of Benefits. Quarterly Journal of Economics, 112, 913-937.

Collins, Ann, et al. (2000). National Study of Low-Income Child Care: State and Community Sub-study Interim Report. Cambridge, MA: Abt Associates.

Giannarelli, L., Phillips, K. and Oliver, H. (2001). How TRIM3 Models Eligibility for CCDF Subsidies. Washington, DC: Urban Institute Memo.

Greene, William (2003). Econometric Analysis (5th ed.). Upper Saddle River, NJ: Prentice Hall. Heckman, J. J., LaLonde, R. J. and Smith, J. A. (1999), The Economics and Econometrics of Active Labor Market Programs. In Orley C. Ashenfelter and David Card (eds). Handbook of Labor Economics, Vol. 3A. Amsterdam: Elsevier.

Lemke, R., Witt, R. and Witte, A. (2001). Child Care and the Welfare to Work Transition, Working Paper 2001-02, Department of Economics, Wellesley College, Wellesley, MA. Available: http://www.wellesley.edu/Economics/wkpapers/index.html.

Meyers, M. et al. (2001). The Dynamics of Child Care Subsidy Use: A Collaborative Study of Five States. Paper presented at the NICHD and Russell Sage Conference "From Welfare to Child Care: What Happens to Infants and Toddlers When Single Mothers Exchange Welfare for Work, Washington, DC, May17-18.

Queralt, M., A. Witte and H. Griesinger. (2000). Changing Policies, Changing Impacts: Employment and Earnings of Child Care Subsidy Recipients in the Era of Welfare Reform. Social Service Review, 74, 588-619.

Rhode Island KIDS COUNT (1996-2000). Rhode Island Kids Count Factbook. Providence, RI: Rhode Island KIDS COUNT).

U.S. Bureau of the Census (2002). Census 2000 Data for the State of Rhode Island and for the Nation. Available from http://www.census.gov/census2000/states/ri.html and from http://www2.census.gov/census 2000/datasets/Summary File 3/0 National/ 
Witte, Ann; Queralt, Magaly; Chipty, Tasneem; \& Griesinger, Harriet (1998). Unintended Consequences: Welfare Reform and the Working Poor. Working paper \#6798. Cambridge, MA: National Bureau of Economic Research.

Witte, Ann; Queralt, Magaly; \& Tauchen, Helen (2001). Evaluation of Rhode Island's Family Independence Program. Working Paper 2001-08. Wellesley, MA: Wellesley College Department of Economics.

Witte, Ann \& Queralt, Magaly (2002). Take-Up Rates and Trade Offs After the Age of Entitlement: Some Thoughts and Empirical Evidence for Child Care Subsidies. Working Paper \#8886. Cambridge, MA: National Bureau of Economic Research, Inc.

Wooldridge, Jeffrey (2002). Econometric Analysis of Cross Section and Panel Data. Cambridge, MA: The MIT Press. 


\section{Figure 1}

\section{Statuses for Current \& Former Cash-Assistance Recipients}

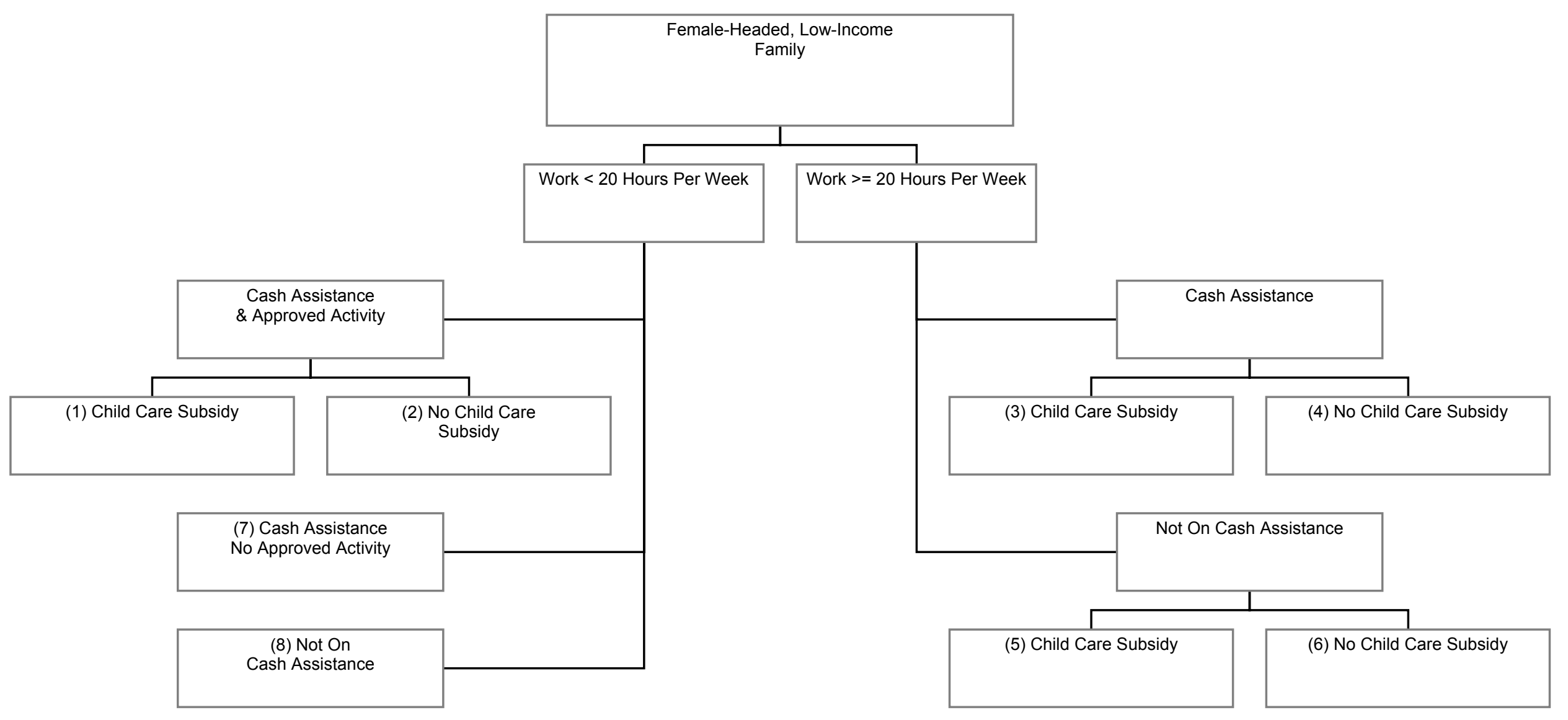


Figure 2

Number of Families with Child Care Subsidies

Rhode Island-May 1996-April 2000

\begin{abstract}
$\multimap$ I.E. Never on Cash $\multimap-$ I.E. Former Cash $\rightarrow-$ Now On Cash $\rightarrow$ Transitional $\rightarrow$ Other $\rightarrow$ Total
\end{abstract}

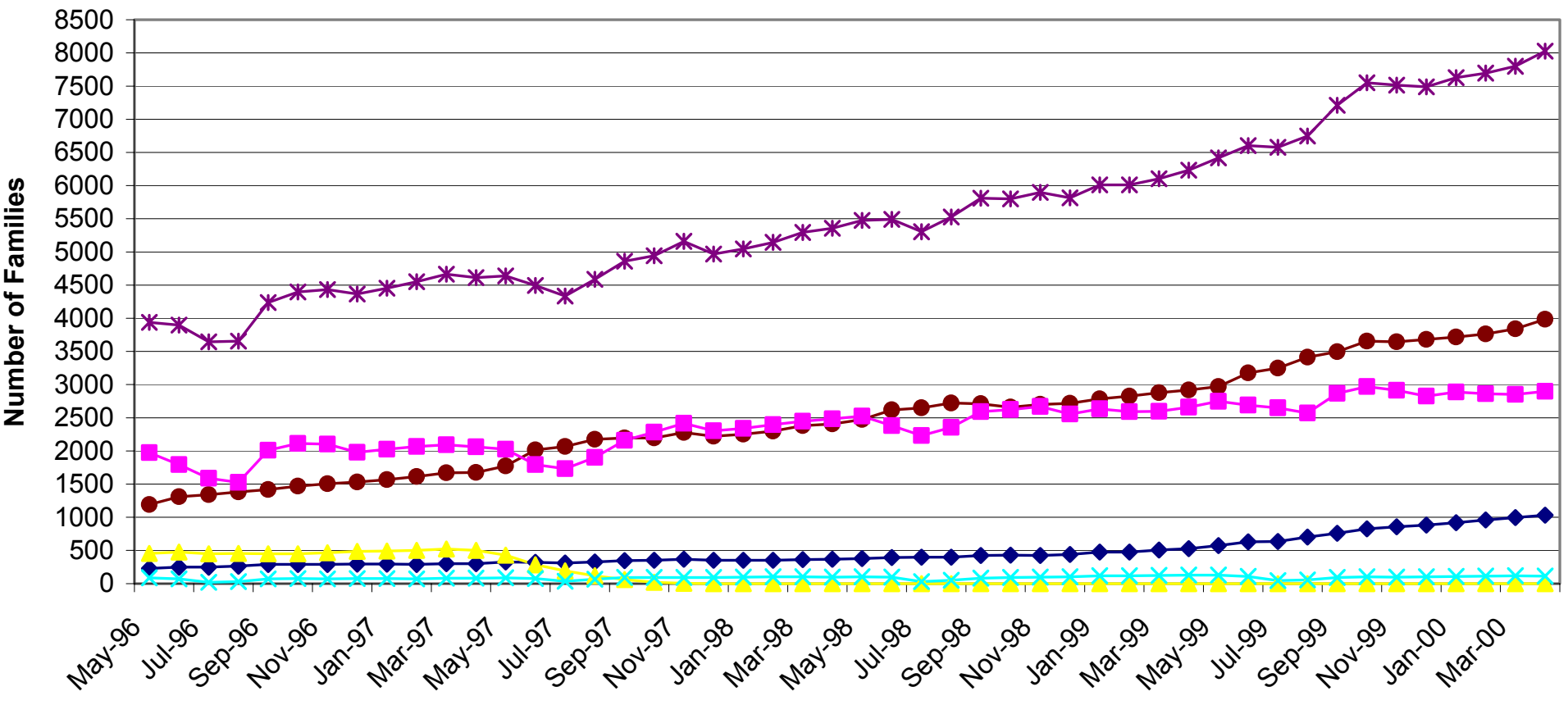


Figure 3

Rhode Island Take-Up Rates for Child Care Subsidies

All Current and Former Cash Recipients--Q2 of 1996 to Q2 of 2000

$n=29,253$

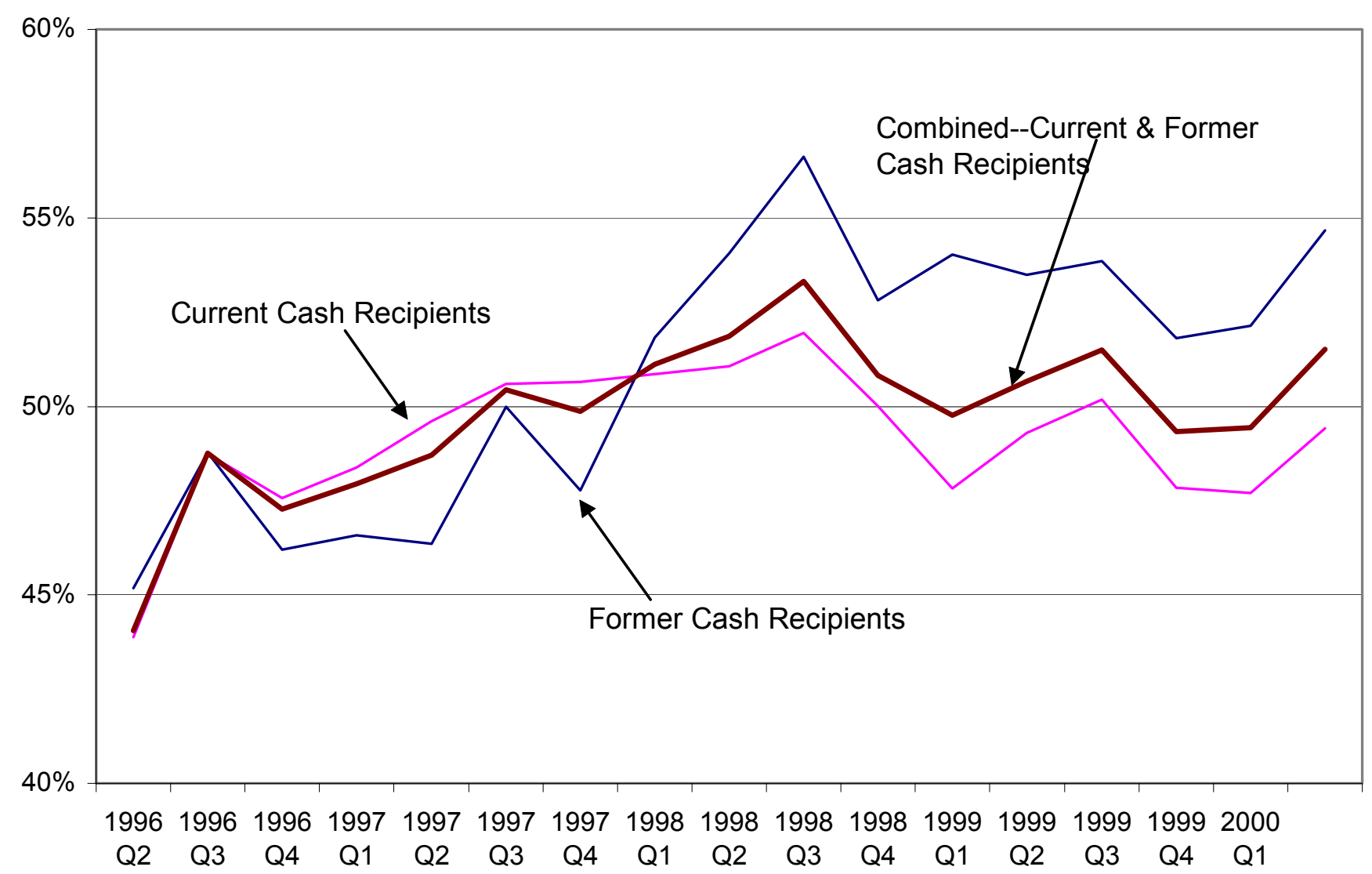




\section{Figure 4}

Estimated Probabilities

Sample Member with Median Characteristics

Rhode Island-May 1996-April 2000

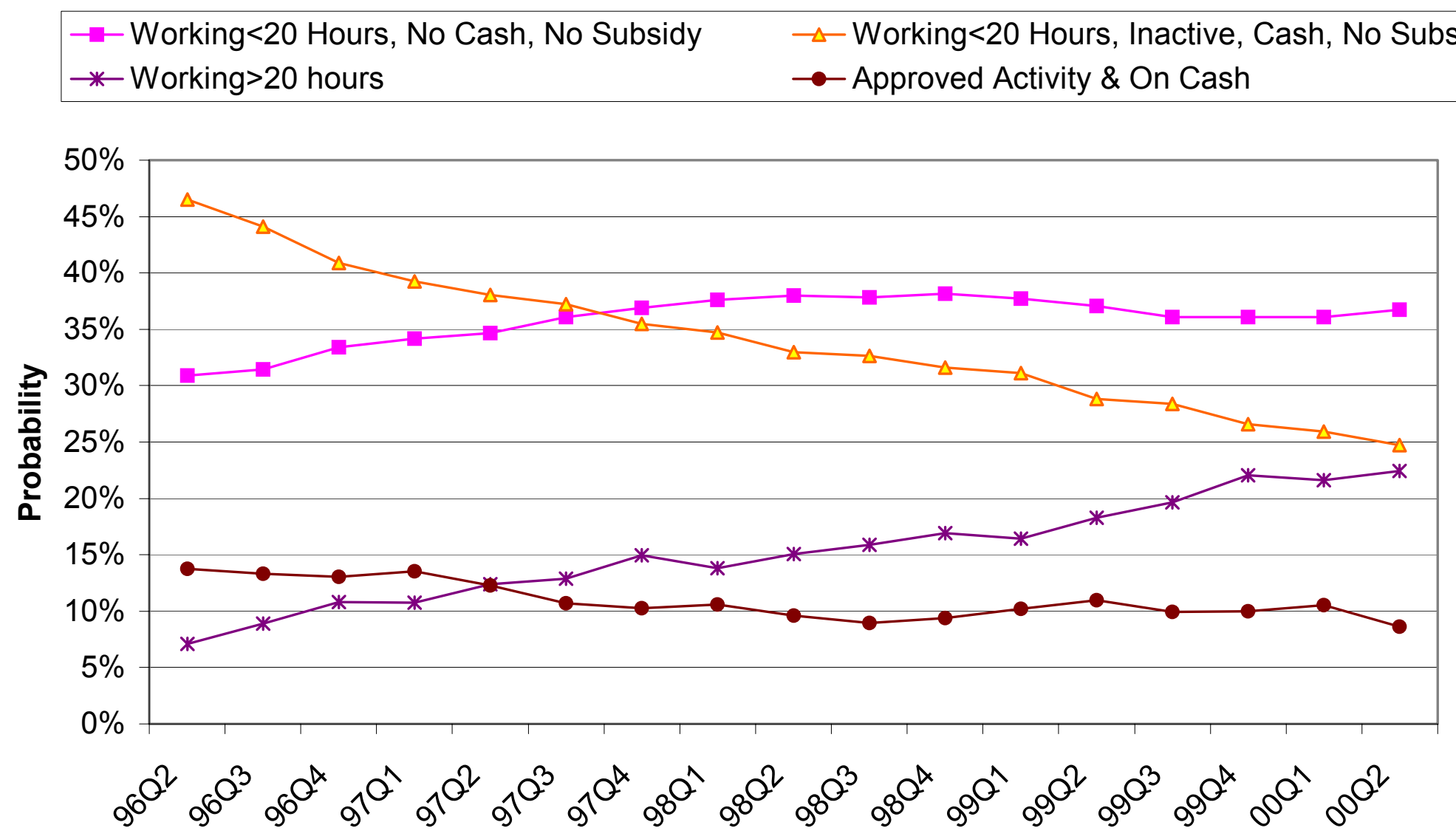




\section{Figure 5}

Probabilities of Being in Statuses 1-6 in Figure 1

Current \& Former Cash Assistance Recipients

Rhode Island-May 1996-April 2000

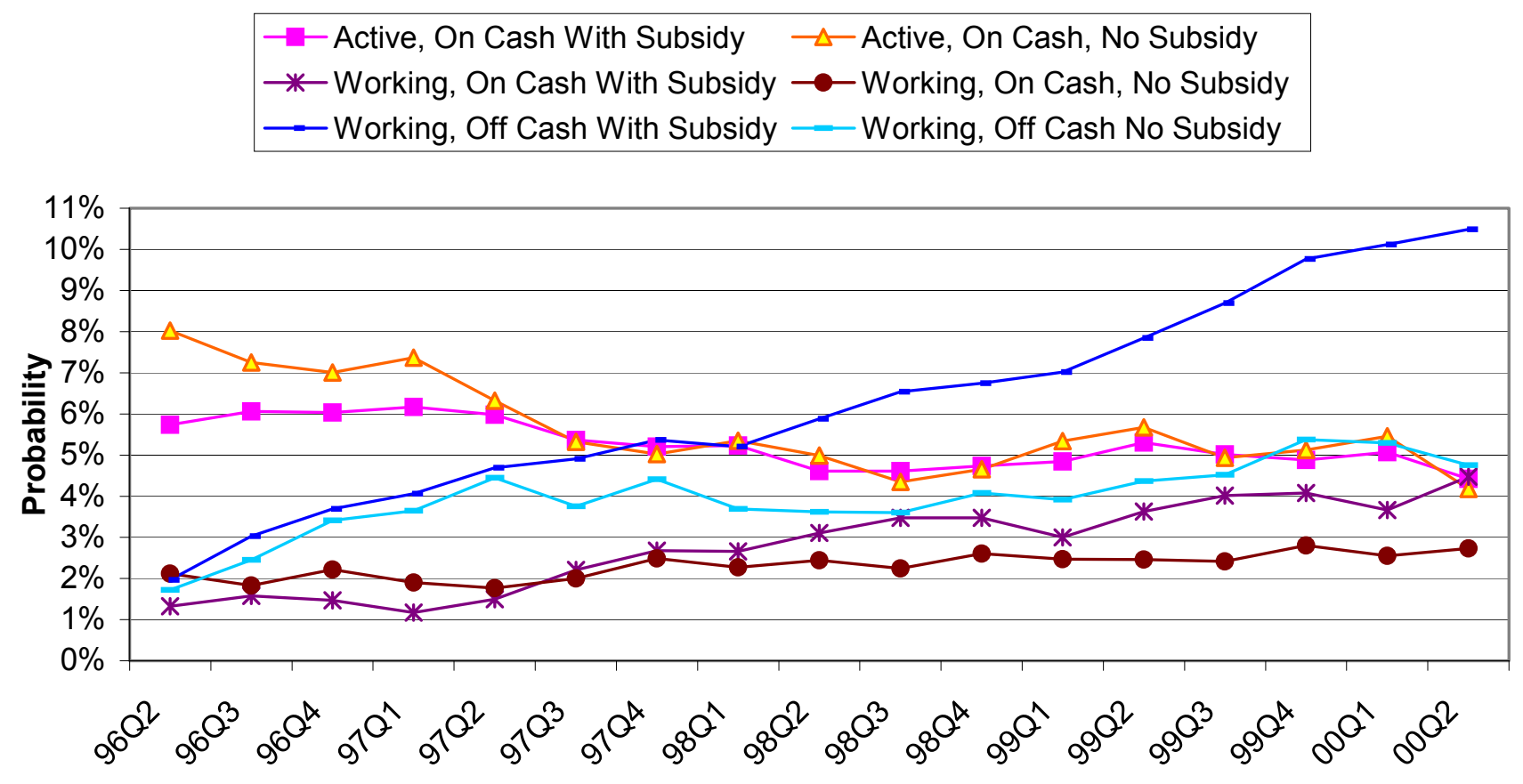




\section{Table 1}

\section{Descriptive Statistics for Explanatory Variables Study Period: Q2 of 1996 to Q2 of 2000}

EXPLANATORY VARIABLES:

Human Capital and Socio-Demographic:

Binary $=1$ if Household Head Has 12 or More Years of Education

Age of Household Head

Household language is English

Household language is Spanish

Asian

Black

Hispanic

White

Number of Children Eligible for Child Care Subsidies

Age of Youngest Child

Fraction of Eligible Children $<12$ Months

Fraction of Eligible Children 1 to 3 Years Old

Fraction of Eligible Children 3 to 5 -Not Kindergarten Eligible

Fraction of Children Eligible for Both Child Care Subsidies \& Kindergarten Number of children 13-17 years old--Middle \& Secondary School Age

Number of Family Members ages 18-60

Number of Disabled Persons in Household

Head of Household Is Disabled

Head of Household Is Not a US Citizen

Household Size

\section{Availability of Care and Education:}

Number of Full-Time Preschool Center Slots per 100 Children <5 in Township in 1996

Number of School-Age Center Slots per 100 School-Age Children in Township in 1996

Number of Family Child Care Slot per 100 Children 0-13 in Township in 1996

Proportion of Eligible 3-4 Year Olds Enrolled in Head Start in Township: in 1997 it was

Proportion of Eligible Children in Part-Day Kindergarten in Township: in 1997 it was

Proportion of Eligible Children in Full-Day Kindergarten in the Township: in 1997 it was Local Labor Market Conditions:

Average Monthly Change in Number Employed During the Quarter (\%)

Time:

A Set of Binary Variables, One for Each Quarter Except Q2 of 1996

\section{Core Communities:}

Client resides in Central Falls Client resides in Newport Client resides in Pawtucket Client resides in Providence Client resides in Woonsocket
Standard

Median Mean Deviation

$0.00 \quad 0.46$

0.50

30.1230 .97

8.61

$1.00 \quad 0.84$

0.37

$0.00 \quad 0.13$

0.34

$0.00 \quad 0.03$

0.17

$0.00 \quad 0.13$

0.33

$0.00 \quad 0.24$

0.43

$1.00 \quad 0.54$

0.50

$2.00 \quad 1.97$

1.08

$4.34 \quad 5.02$

0.76

$0.00 \quad 0.09$

0.25

$0.00 \quad 0.16$

0.31

$0.00 \quad 0.19$

0.32

$0.00 \quad 0.08$

0.22

$0.00 \quad 0.25$

0.60

$1.00 \quad 1.02$

0.27

$0.00 \quad 0.08$

0.30

$0.00 \quad 0.01$

0.07

$0.00 \quad 0.13$

0.33

$2.00 \quad 2.77$

1.07

22.0019 .04

6.97

$7.00 \quad 5.96$

1.68

$2.48 \quad 3.00$

0.70

$\begin{array}{ll}0.34 & 0.41\end{array}$

0.20

$\begin{array}{ll}0.73 & 0.73\end{array}$

0.18

$\begin{array}{ll}0.14 & 0.21\end{array}$

0.21

$0.28 \quad 0.14$

0.97

$\begin{array}{ll}0.00 & 0.05\end{array}$

0.21

$0.00 \quad 0.03$

0.18

$0.00 \quad 0.11$

0.32

$0.00 \quad 0.38$

0.48

$0.00 \quad 0.08$

0.27 
Table 2

Percent Change in Odds that a Sample Member Will Receive a Child Care Subsidy $\left(\left(1-(P(\text { Status } \mathrm{i}) / \mathrm{P}(\text { Status } \mathrm{j}))^{\star} 100\right)\right.$

\begin{tabular}{|c|c|c|c|c|c|c|}
\hline Quarter & $\begin{array}{c}\% \Delta \text { Odds } \\
\text { (Status } 1 / \text { Status } 2)\end{array}$ & P-Value & $\begin{array}{c}\% \Delta \text { Odds } \\
\text { (Status3/Status4) }\end{array}$ & P-Value & $\begin{array}{c}\% \Delta \text { Odds } \\
\text { (Status5/Status6) }\end{array}$ & P-Value \\
\hline 1996 Q3 & $17 \%$ & 0.00 & $39 \%$ & 0.00 & $8 \%$ & 0.34 \\
\hline 1996 Q4 & $21 \%$ & 0.00 & $6 \%$ & 0.50 & $-6 \%$ & 0.51 \\
\hline 1997 Q1 & $17 \%$ & 0.00 & $-1 \%$ & 0.93 & $-3 \%$ & 0.75 \\
\hline 1997 Q2 & $33 \%$ & 0.00 & $36 \%$ & 0.00 & $-8 \%$ & 0.35 \\
\hline 1997 Q3 & $41 \%$ & 0.00 & $78 \%$ & 0.00 & $14 \%$ & 0.15 \\
\hline 1997 Q4 & $45 \%$ & 0.00 & $73 \%$ & 0.00 & $6 \%$ & 0.49 \\
\hline 1998 Q1 & $37 \%$ & 0.00 & $88 \%$ & 0.00 & $24 \%$ & 0.03 \\
\hline 1998 Q2 & $49 \%$ & 0.00 & $105 \%$ & 0.00 & $42 \%$ & 0.00 \\
\hline 1998 Q3 & $48 \%$ & 0.00 & $150 \%$ & 0.00 & $59 \%$ & 0.00 \\
\hline 1998 Q4 & $43 \%$ & 0.00 & $115 \%$ & 0.00 & $45 \%$ & 0.00 \\
\hline 1999 Q1 & $27 \%$ & 0.00 & $96 \%$ & 0.00 & $56 \%$ & 0.00 \\
\hline 1999 Q2 & $31 \%$ & 0.00 & $137 \%$ & 0.00 & $57 \%$ & 0.00 \\
\hline 1999 Q3 & $42 \%$ & 0.00 & $168 \%$ & 0.00 & $68 \%$ & 0.00 \\
\hline 1999 Q4 & $33 \%$ & 0.00 & $134 \%$ & 0.00 & $59 \%$ & 0.00 \\
\hline 2000 Q1 & $67 \%$ & 0.00 & $131 \%$ & 0.00 & $67 \%$ & 0.00 \\
\hline 2000 Q2 & $48 \%$ & 0.00 & $164 \%$ & 0.00 & $93 \%$ & 0.00 \\
\hline
\end{tabular}

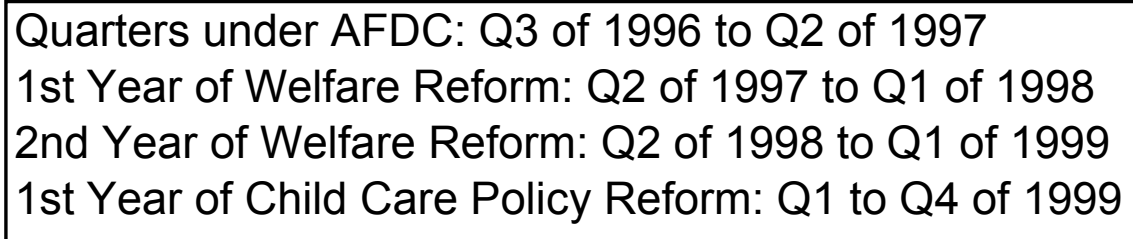


Table 3

State of Rhode Island

Probability that Current and Former Single-Parent Welfare Families Will Take Up Subsidies

\section{Status}

(1) Active On Cash Assistance

(3) On Cash Working 20+ hours

(5) Off Cash Working 20+ hours

\section{Q2 of 1996 to $\mathbf{Q 1}$ of 1997}

$47 \%$

$31 \%$

$42 \%$

\section{Q3 of 1999 to $\mathbf{Q 2}$ of 2000}

$49 \%$

$44 \%$

$58 \%$ 


\section{Table 4}

Differences \& Difference in the Differences

(P-Values using Robust Standard Errors in Parentheses)

\begin{tabular}{|c|c|c|c|c|}
\hline \multirow[b]{2}{*}{ Statuses } & \multicolumn{3}{|c|}{ Mean Probability Mean Probability P(After)- } & \multirow[b]{2}{*}{ Diff in Diff } \\
\hline & Before* $^{*}$ & After* & $\mathrm{P}$ (Before) & \\
\hline Status 1 (On Cash, Active, Receiving Subsidy) & 0.054 & 0.049 & $\begin{array}{c}-0.005 \\
(0.01)\end{array}$ & \\
\hline Status 2 (On Cash, Active, No Subsidy) & 0.060 & 0.051 & $\begin{array}{c}-0.008 \\
(0.08)\end{array}$ & \\
\hline (Status 1_P(After)-P(Before))-(Status 2_P(After)-P(Before)) & & & & $\begin{array}{l}0.003 \\
(0.70)\end{array}$ \\
\hline Status 3 (On Cash, Working, Receiving Subsidy) & 0.022 & 0.038 & $\begin{array}{l}0.016 \\
(0.00)\end{array}$ & \\
\hline Status 4 (On Cash, Working, No Subsidy) & 0.022 & 0.026 & $\begin{array}{l}0.004 \\
(0.09)\end{array}$ & \\
\hline (Status 3_P(After)-P(Before))-(Status 4_P(After)-P(Before)) & & & & $\begin{array}{l}0.012 \\
(0.00)\end{array}$ \\
\hline Status 5 (Off Cash, Working, Receiving Subsidy) & 0.047 & 0.090 & $\begin{array}{l}0.043 \\
(0.00)\end{array}$ & \\
\hline Status 6 (Off Cash, Working, No Subsidy) & 0.035 & 0.047 & $\begin{array}{l}0.012 \\
(0.00)\end{array}$ & \\
\hline (Status 5_P(After)-P(Before))-(Status 6_P(After)-P(Before)) & & & & $\begin{array}{l}0.031 \\
(0.00)\end{array}$ \\
\hline
\end{tabular}

*Before Period: Q2 of 1996 to Q4 of 1998

*After Period: Q1 of 1999 to Q2 of 2000 